Mailman School of Public Health, Columbia University, New York, New York and Institute for

Cancer Prevention, Valhalla, New York

\title{
Issues of causality in the history of occupational epidemiology
}

\section{Summary}

Occupational epidemiology has its roots in classical medicine. However, it became a quantitative discipline only in the $20^{\text {th }}$ century, through the pioneering work of individuals such as Case, Lloyd, and Selikoff and organizations such as the Division of Occupational Health of the U.S. Public Health Service. Studies of chemical dye workers, bituminous coal miners, smelting workers, and uranium miners have been especially important sources of innovations in methodology and in development of logical reasoning leading to acceptance of causal relationships of occupational exposures that lead to respiratory diseases and cancer. The cooperation of labor unions, such as those of steel and asbestos workers, has often been a crucial factor in providing essential data.

Keywords: Occupation - Epidemiology - History - Causality - Epidemiologic methods.

Occupational epidemiology traces its origins at least as far back as the 1755 treatise of James Lind on his intervention trial of citrus fruits to prevent scurvy among sailors in the British Navy (Lind 1757; 1974). However, the application of scientific methods to recognition and amelioration of conditions in industry has occurred only in recent times. Before about 1950, research into causes of occupational diseases generally used methods that were little more than quantitative extensions of clinical medicine, and relied largely on cross-sectional observations at various points in time. As hazards associated with long-term exposure to carcinogens and other causes of chronic disease came under investigation, new research methods were developed.

In this paper I draw on a number of studies - some wellknown, others relatively obscure - that I regard as milestones in the development of concepts and tools of occupa- tional epidemiology. The studies cover a variety of workplaces including the chemical industry, mining, and asbestos insulation work. The methods involved either were invented because there was no existing methodology to handle the unique workplace situations, or were innovative adaptations of existing methods which were inadequate in their current forms. The developers of these methods have often had to show great resourcefulness and creativity, for the work environment is frequently inhospitable (and more than occasionally hostile) to the needs of the epidemiologist.

\section{The birth of occupational cohort studies}

The study by R.A.M. Case of the Institute of Cancer Research at the Royal Cancer Hospital, London, on causes of bladder cancer in the British chemical industry is widely regarded as the "prototype of historical cohort studies" (Case et al. 1954; Case \& Pearson 1954; Breslow \& Day 1987). Reports of bladder cancer among chemical dye workers had appeared in the $19^{\text {th }}$ century (Rehn 1895), and in a 1921 report the International Labour Office (ILO) listed benzidine and $\beta$-naphthylamine as likely causes (Averill \& Samuels 1992). The goal of Case's study was to determine "whether the manufacture or use of aniline, benzidine, $\alpha$-naphthylamine, or $\beta$-naphthylamine could be shown to produce tumours of the urinary bladder in men so engaged". Case prepared a list of all men who had been employed by 21 cooperating chemical firms for at least six months between 1920 and 1952, and for whom exposure to one of the target chemical compounds could be documented. He then searched British death certificates for any that mentioned bladder cancer, and determined which belonged to men in their list. From known death rates from bladder cancer he calculated the "expected" number of deaths for bladder cancer workers. The observed number of bladder cancer deaths far exceeded the number expected on the basis of prevailing rates. An important methodological innovation was the examination of 
Table 1 Mortality in 1267 World War I veterans followed up 1930-1952 by wartime exposure to mustard gas (Case \& Lea 1955)

\begin{tabular}{|c|c|c|c|c|c|c|c|c|c|}
\hline \multirow[t]{3}{*}{ Cause of death } & \multicolumn{3}{|c|}{ Exposed to mustard gas } & \multicolumn{6}{|c|}{ Not exposed to mustard gas } \\
\hline & \multirow[b]{2}{*}{$\operatorname{Exp}^{a}$} & \multirow[b]{2}{*}{ Obs $^{b}$} & \multirow[b]{2}{*}{ SMR } & \multicolumn{3}{|c|}{ Bronchitis } & \multicolumn{3}{|c|}{ Amputation } \\
\hline & & & & $\operatorname{Exp}^{a}$ & Obs $^{b}$ & SMR & $\operatorname{Exp}^{a}$ & Obs $^{b}$ & SMR \\
\hline All causes & 357.3 & 547 & $153 * * *$ & 673.8 & 932 & $138 * * *$ & 365.7 & 383 & 105 \\
\hline All cancers & 60.8 & 79 & $130 *$ & 95.0 & 104 & 109 & 72.2 & 72 & 100 \\
\hline Lung cancer & 14.0 & 29 & $207 * *$ & 14.4 & 29 & $201 * *$ & 15.5 & 13 & 84 \\
\hline Cancers other than lung & 46.8 & 50 & 107 & 80.6 & 75 & 93 & 56.7 & 59 & 104 \\
\hline
\end{tabular}

* $\mathrm{P}<0.05 ; * * \mathrm{P}<0.01 ; * * * \mathrm{P}<0.0001$.

${ }^{\mathrm{a}}$ Expected; ${ }^{\circ}$ Observed.

expected deaths in relation to the number of years since first employment, the so-called "latency" period. This concept has by now become a central feature of cancer epidemiology. In 1955 Case and Lea reported a two-fold increase in deaths from lung cancer among men who suffered from mustard gas poisoning in World War I (Tab. 1) (Case \& Lea 1955). Their cohort study contains several innovative points. First, they asserted that the circumstances and dates of the mustard gas release were so well established and the affected population so well characterized through military and veteran records that they offered an analogy to "a carefully planned animal experiment." Secondly, they used two different non-exposed groups for comparison (men pensioned with bronchitis but who had never been exposed to mustard gas and unexposed amputees). Third, nine years before publication of the US Surgeon-General's Report on Smoking and Health, the authors recognized and demonstrated possible confounding by cigarette smoking.

Predicting that their work might be a prototype for a new genre of "environmental cancer studies", Case and Lea (1955) provided many details of their analytic method, which they termed a "comparative composite cohort analysis" to distinguish it from the cross-sectional analyses of mortality by occupation regularly published by the UK Registrar-General (1938). Their exposition of the use of agestratified person-years is a model of clarity. This pathbreaking study was one of the earliest to make use of the standardized mortality ratio, a measure that is now one of the most common ways of expressing the magnitude of a health outcome in cohort studies (Stellman et al. 1998).

\section{Mining, smelting, and coke-ovens: spawning ground for epidemiologic methods}

The health hazards of mining have been known since antiquity. Pliny the Elder (23-79 AD) described devices used by metal refiners to prevent the inhalation of fatal dust (Plinius Secundus Tr1929) (he himself died of asphyxiation while in- vestigating the eruption of Vesuvius). In his 1556 treatise on mining and metallurgy De Re Metallica the German physician and mineralogist Georgius Agricola noted that "the evils which affect miners" included shortness of breath and premature death (Agricola $\operatorname{Tr} 1950$ ). Ramazzini, the father of occupational medicine, also provided clinical descriptions of diseases of miners $(\operatorname{Tr} 1940)$.

\section{Pneumoconiosis - a mine worker's disease}

In the mid- $19^{\text {th }}$ century physicians began to systematically distinguish among the many forms of mining related illnesses (Pendergrass et al. 1972). In 1837 Thomson noted that British coal miners frequently had black deposits in their lungs at death (Lainhart et al. 1969). The term "pneumoconiosis" was coined by Zenker (1867), and "silicosis" by Visconti (1870). However, over half a century elapsed before epidemiological studies of miners were carried out. Doyle (1969) has written:

"Although the medical literature of the 19th century contained frequent warnings that coal miners suffered from an unusual chest disease, the first investigation was not made until 1928. In that year, Collins and Gilchrist (1928) in the UK published a paper that precipitated a long and detailed investigation of chest diseases among bituminous coal workers in Great Britain. Studies were initiated in 1936 by the Committee on Industrial Pulmonary Diseases of the Medical Research Council ..."

"Although coal pneumoconiosis was recognized on the European continent about 1935, it was the establishment of the European Coal and Steel Community in 1952 that brought about a coordinated effort to study and prevent the disease. ... Over the next ten years, coal pneumoconiosis was recognized as a compensable disease in each of the European coal producing countries. ... Many research laboratories contributed to fundamental knowledge of the pathology and physiology of dust-induced diseases, with emphasis on coal pneumoconiosis. Environmental controls were developed, tested, and 
implemented, based on the principles of dust suppression at the coal face by water infusing and spray, ventilation, and respirators. Workplace dust monitoring and medical surveillance programs were instituted".

No comparable body of knowledge or programs then existed in the United States, where it was believed that bituminous coal did not produce a disabling pneumoconiosis, even though anthracosilicosis was well known in anthracite miners. Not until 1952 did the Division of Occupational Health of the USPHS (United States Public Health Service) conclude that a major cause of morbidity among bituminous coal miners was chronic diseases of the respiratory system. In the early 1960s, studies in Western Pennsylvania showed that $4 \%$ of working miners under age $45,15 \%$ of working miners age 45 year or older, and $29 \%$ of retired miners had the disease. However, the sample size was small and lacked consistency between X-ray findings and symptom reports. Other studies suffered from flaws of subject selection, exclusion of retirees who might have left employment because of job-related illness, and consideration of the social environment within the extremely impoverished mining areas of Appalachia.

In 1963 the USPHS initiated The Appalachian Bituminous Coal Miners Study in the region where the majority of American coal miners live and work. The study drew a sample of 2000 working and 1000 nonworking miners, using a two-stage random selection of mines with stratification by and control for subsample size. The sample was drawn in stages from working miners in 97 counties grouped in 17 strata which averaged 6000 miners each, so as to select workers in small and large mines. To overcome the lack of a national roster of nonworking miners, the cooperation of the United Mine Workers of America was obtained. The study could not have been carried out without this collaboration. A total of 2751 working miners were identified, of whom $93 \%$ were examined. The researchers examined 617 unemployed miners and 574 pensioners, or $82 \%$ and $89 \%$ of those identified, respectively. Medical histories were gathered using the standardized Medical Research Council questionnaire (Lainhart et al. 1969).

Besides a rigorous sampling scheme, two important methodological decisions characterized the study design. First, the survey was restricted to men under age 65 , recognizing that severe illnesses contracted during mine work produce a biased sample of men above retirement age. Second, separate samples of working miners and "non-working" miners were drawn, in recognition that many men left the industry before age 65 because of work-related health conditions.

Ten percent of working miners and $20 \%$ of nonworking miners had objective X-ray evidence of pneumoconiosis. X-ray findings also showed a high prevalence of definite pneumoconiosis which differed by job type and location underground, e.g., $22.3 \%$ in cutting machine operators. The prevalence of $\mathrm{X}$-ray evidence of pneumoconiosis was also related directly to years of underground experience. X-ray abnormalities were definitely related to coal mining; they were not found in other workers living in the same area; they were clearly related to years of work and type of exposure. The disease was clinically identical to that in bituminous coal miners in Great Britain.

\section{Mine radiation as a cause of lung cancer}

The Erz Mountains of central Europe have been mined for metals since the Middle Ages (Fig. 1). In medieval times the peculiar illnesses ("Bergsucht") acquired by local miners were well known. In 1879 Härting and Hesse noted the high percentage of deaths from "Bergkrankheit" (lung cancer) among miners in Schneeberg and Joachimsthal (Härting \& Hesse 1879). In the early 1900s, arsenic and cobalt were suspected causes, but Lorenz (1944) identified radioactivity definitively as a causative agent in the Schneeberg and Joachimsthal mines, and by 1949 the daughters of radioactive decay of radon released in the lungs by inhaled particles were identified as principal causes.

In 1950 the USPHS in cooperation with other Federal and State agencies initiated a program to assess hazards

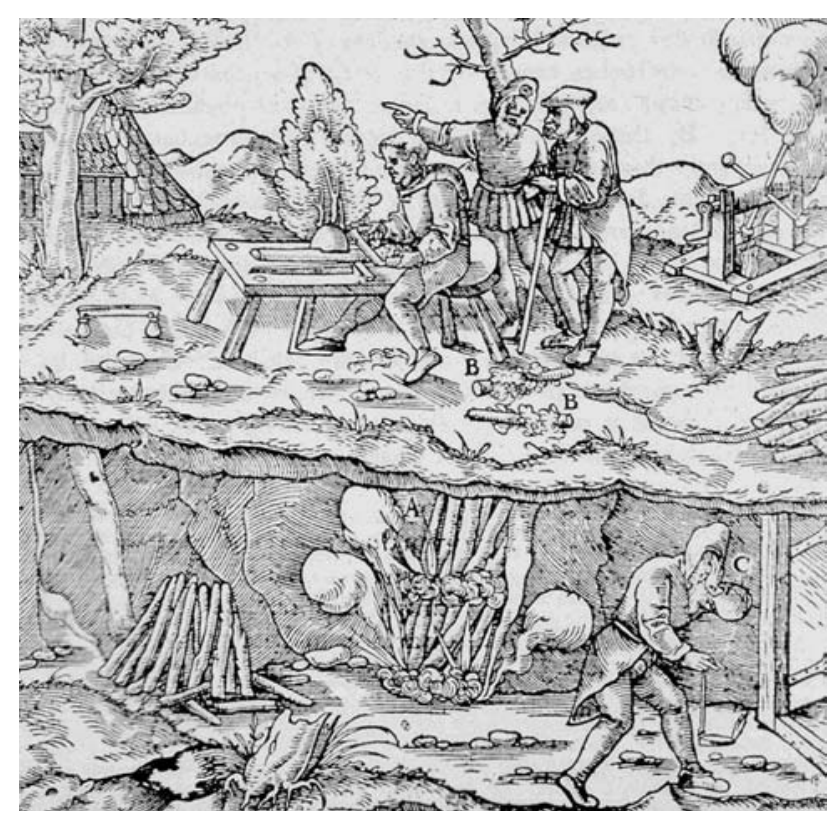

Figure 1 Mining in the Middle Ages, as depicted by Agricola 1556 (Tr1950). Fires were set to shatter rocks and break open veins of metal ore, as this man has done who is obviously on his way out. Agricola wrote, "While the heated veins and rock are giving forth a foetid vapor and the shafts or tunnels are emitting fumes, the miners and other workmen do not go down in the mines lest the stench affect their health or actually kill them." 
of internal radiation emitters. By 1962, Archer and colleagues had shown that lung cancer risk among uranium miners was higher than in the general population of White males (Archer et al. 1962), and in 1964 Wagoner and colleagues reported a 10 -fold excess of respiratory cancer among long-term underground uranium miners in the U.S. (Wagoner et al. 1964a; 1964b). Wagoner further showed that the excess was not attributable to age, smoking, nativity, heredity, urbanization, self-selection, diagnostic accuracy, prior mining experience, or silica. The mean cumulative dose of radiation of uranium miners with lung cancer was significantly higher than in matched control miners. That was not enough proof for some. The 1964 Surgeon-General's Report on Smoking and Health stated "although the induction of lung cancer by radionuclides is probable in man, the evidence is not as firm as in animals" (U.S. Public Health Service 1964).

Wagoner and colleagues, drawing on radiation studies conducted by Court Brown and Doll (1957) and others, then constructed a cohort study which utilized statistical life table methods newly developed by Cutler and Ederer (1958). They invoked the Bradford-Hill principles of causality (Hill 1953), citing six factors supporting a causal relationship (Wagoner et al. 1965):

1) Excessive respiratory cancer

2) Dose-response relation between airborne radiation and lung cancer

3) Persistence of excess risk and dose-response after accounting for confounding variables, including time since first exposure and cigarette smoking

4) Consistency with animal studies and studies of other mining populations with similar exposures

5) Specificity for the respiratory tract

6) Lung cancer pathology among miners unlike that observed among age-smoking-residence matched control group, but similar to that of factory workers exposed to mustard gas

The argument in favor of causality was bolstered by a powerful dose-response curve (Fig. 2). Use of a cumulative dose ("working-level months") of exposure to radon progeny, was one of the earliest applications of an external dosage measure in a study of occupational cancer.

\section{Radium dial painters - another cancer hazard}

Indiscriminate exposure to ionizing radiation has occurred in many industries besides mining. From 1915 to 1929 about 2000 US women were employed to paint the faces of clocks and wristwatches with radium paint. By the early 1920s it became clear that many of these women were developing a

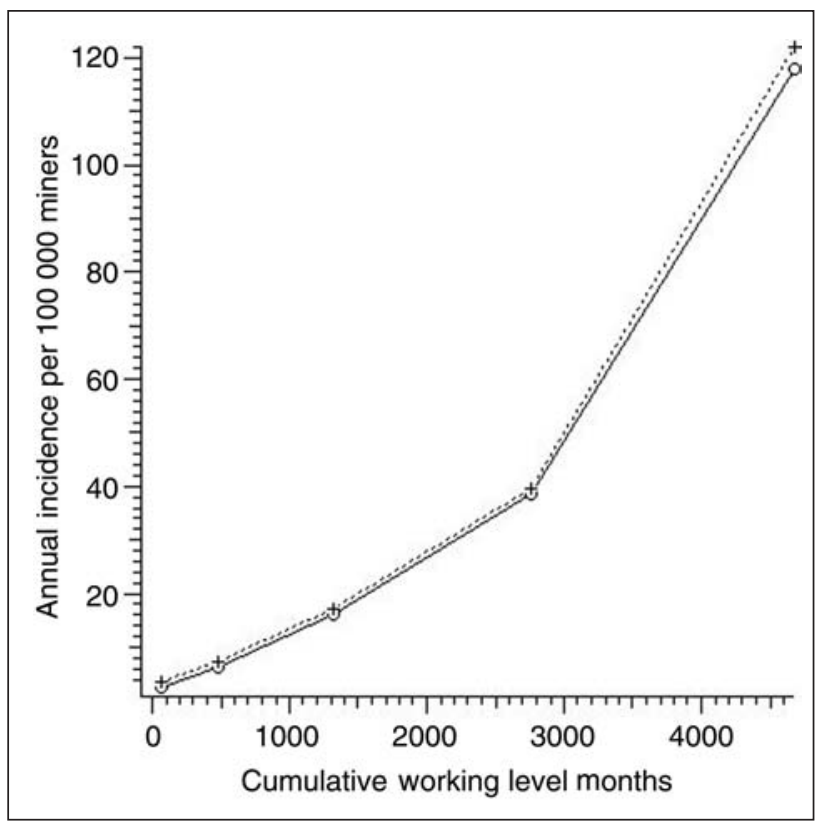

Figure 2 Incidence of lung cancer in underground uranium miners in relation to ionizing radiation dosage, expressed in "working-level months" (Wagoner et al. 1964a)

rare and disfiguring facial cancer of the paranasal sinuses. The U.S. Bureau of Labor Statistics set up a cohort of 1260 women which was later maintained by Argonne National Laboratory. In the 1950s, more than 20 years after most exposure stopped, 396 women were examined, and their body burden of radioactivity measured via a breath exhalation test. The 226 women who were first employed between 1915 and 1924 had a mean body burden of $21.19 \mu \mathrm{Ci}$. Beginning in 1924 it was strictly forbidden for workers to "tip" the brushes in their mouths. This simple industrial hygiene measure reduced the exposure by over $90 \%$, so that 170 women hired between 1925 and 1929 were eventually found to have a mean body burden of only $1.25 \mu \mathrm{Ci}$. Tight control over painting operations was also exercised, with a high degree of work enclosure (Fig. 3). The reduced dosage translated to lower mortality: standard mortality ratios (SMRs), reported by Polednak et al. (1978), are shown in Table 2, subdivided into groups with cumulative radiation below $50 \mu \mathrm{Ci}(\mathrm{N}=$ $302)$ and above $50 \mu \mathrm{Ci}(\mathrm{N}=58)$. Mortality ratios above 1.00 were observed only in the higher intake dose group. The highest SMRs were reported for bone cancer, and "other/unspecified cancer", which is thought to contain tumors in the mandibular region. Note that the body burden measurements were obtained after 1954, so that there is an unknown survival effect on initial selection into the cohort. This is probably the first occupational cohort study to employ a biomarker based upon measurement of a foreign agent in the 


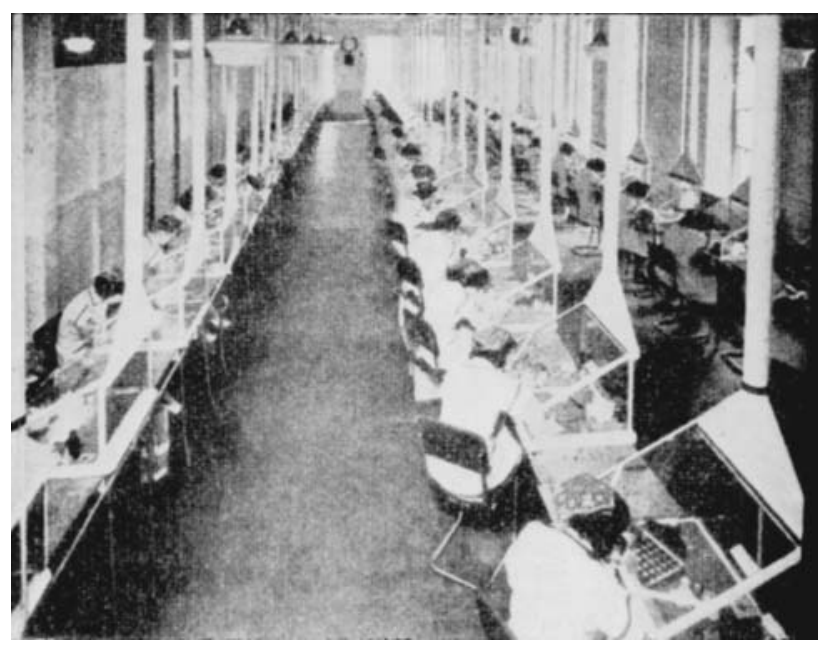

Figure 3 Radium dial painting operation after implementation of industrial hygiene measures including banning of oral "tipping" of brushes and construction of ventilated work enclosures (Hunter 1969)

Table 2 SMRs among 360 radium dial painters by radiation dose as measured after 1954 (Polednak et al. 1978)

\begin{tabular}{llllll}
\hline $\begin{array}{l}\text { Cause } \\
\text { of death }\end{array}$ & $<50 \mu \mathrm{Ci}(\mathrm{N}=\mathbf{3 0 2})$ & & \multicolumn{2}{c}{$\geq \mathbf{5 0} \mu \mathrm{Ci}(\mathrm{N}=\mathbf{5 8})$} \\
\cline { 2 - 3 } \cline { 5 - 6 } $\begin{array}{l}\text { Observed/ } \\
\text { Expected }\end{array}$ & SMR & & $\begin{array}{l}\text { Observed/ } \\
\text { Expected }\end{array}$ & $\mathrm{SMR}$ \\
\hline All causes & $46 / 53.3$ & 0.86 & & $23 / 12.0$ & $1.91^{* *}$ \\
Cancer & $16 / 13.3$ & 1.20 & & $12 / 3.02$ & $3.97 * * *$ \\
Lung & $0 / 0.8$ & - & & $1 / 0.18$ & 5.61 \\
Breast & $3 / 2.8$ & 1.07 & & $1 / 0.62$ & 1.62 \\
Bone & $0 / 0.06$ & - & & $3 / 0.01$ & $225.40^{* * *}$ \\
$\begin{array}{l}\text { Other/ } \\
\text { unspecified }\end{array}$ & $1 / 0.85$ & 1.18 & & $5 / 0.18$ & $22.73^{* * *}$ \\
Leukemia & $0 / 0.44$ & - & & $1 / 0.10$ & 9.95 \\
\hline
\end{tabular}

$* p<0.05 ; * * p<0.01 ; * * * p<0.001$.

body, and perhaps the earliest in which the favorable effects of an intervention were directly measured. By the 1930s, the "luminizing" industry was mostly out of the watch business, and existed largely for military applications.

\section{Hazards of smelting: arsenic and lung cancer}

In modern industry, ores of copper, lead, and zinc are commonly smelted in order to remove impurities, chief among which is arsenic. Besides smelting, occupational exposure to arsenic occurs in production of pesticides and insecticides (including Agent Blue which was used as a defoliant by the U.S. military in Vietnam (Stellman et al. 1988; 2003)), and in agricultural workers who apply these agents (Stellman \& Kabat 1978). Heavy exposure in workers has been well documented: Pinto and McGill (1953) found high levels of urinary arsenic in 348 workers exposed to arsenic trioxide dust at ASARCO's Tacoma, Washington, smelter. By mid$20^{\text {th }}$ century it had become contentious whether arsenic or its compounds were carcinogens.

Using company records, Pinto and Bennett (1963) reported an elevated PMR of 174 for lung cancer among 904 active employees and 209 pensioners, a finding which Milham and Strong (1974) corroborated independently with a PMR of 222. However, proportional mortality ratios, while suggestive, are not generally regarded as being methodologically as strong as cohort data.

In the late 1960s researchers from the NCI and USPHS constructed a cohort of 8047 white male smelter workers with exposure of one year or more to arsenic trioxide between 1938 and 1963. The SMR for lung cancer was $329(\mathrm{p}<0.01)$, and was eight-fold in workers with more than 15 years of employment and heavy exposure to arsenic (Lee \& Fraumeni 1969). The study had two innovative features. First, air measurements were used to classify various work areas as providing qualitatively light, medium, or heavy exposure. Since exposure assignments were based on job titles, this is probably one of the earliest examples of what we now call a jobexposure matrix. Secondly, the men were split into five subcohorts according to length of employment, so as to allow for latency and to provide stratification by calendar year. Lee and Fraumeni concluded that their findings were consistent with the "hypothesis that exposure to high levels of $\mathrm{As}_{2} \mathrm{O}_{3}$, perhaps in interaction with $\mathrm{SO}_{2}$ or unidentified chemicals in the work environment, is responsible for the excessive number of respiratory cancer deaths among smelter workers". In 1987 IARC definitively classified both arsenic and its compounds as human carcinogens (International Agency for Research on Cancer 1987).

\section{Coke oven workers and lung cancer}

The health hazards associated with bituminous coal do not end at the mine shaft. When bituminous coal is heated to a high temperature $\left(350-1000^{\circ} \mathrm{C}\right.$.) in the absence of air, volatile products are formed and a residue of impure carbon remains, known as coke. When the volatile products cool to ambient temperature, a portion condenses to a black viscous liquid known as coal tar, while the noncondensable gases are known as coal gas. The coke itself is used for the reduction of ores in blast furnaces, a process which is an integral part of steel manufacture (Fig. 4). The by-product coke plant, designed to maximize recovery of valuable tar, oils, and chemicals from the volatiles, was the dominant type through midcentury. Many of these by-products are carcinogens or carcinogen precursors. 


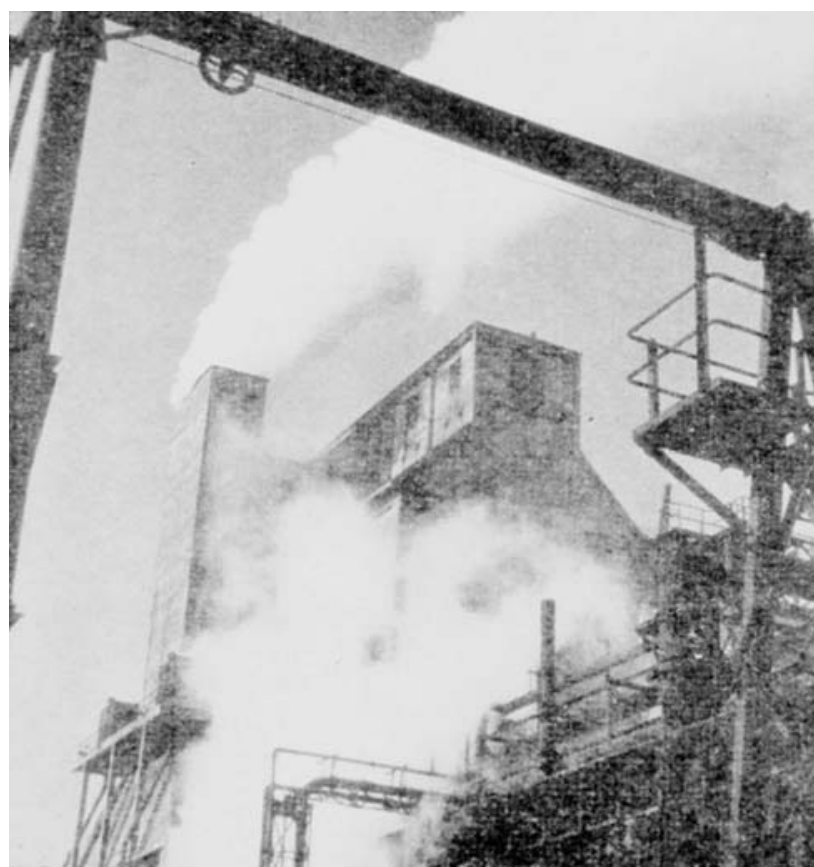

Figure 4 Coke oven plant in which bituminous coal is converted to coke for subsequent use in blast furnaces as an integral part of manufacture of steel. Workers assigned to "topside" positions closest to the top of the stack had highest rates of lung cancer (Hunter 1969)

Until the 1960s, contradictory findings had been reported regarding lung cancer among coke-oven workers. In 1962 William Lloyd of the USPHS and Antonio Ciocco of the University of Pittsburgh School of Public Health set up a historical cohort of over 59000 steelworkers in seven plants in the Pittsburgh area. This cohort represented nearly twothirds of all men working in basic iron and steel production in the U.S. in 1953. The study achieved an extraordinarily low rate of $0.2 \%$ loss to follow-up. Whites had lower death rates than Blacks, and both groups had favorable mortality compared with the general population, although White steelworkers had an excess of deaths due to accidents (Lloyd \& Ciocco 1969).

Shortly after this initial report, Carol Redmond joined the study team, and contributed to a series of landmark publications in the Journal of Occupational Medicine. One report assessed risk of lung cancer among coke plant workers. The byproduct coke plant was a semi-continuous operation with three distinct work areas in terms of function and potential exposure to environmental hazards: (1) the coal handling area where coal is received by rail or barge and possibly blended with other coal types; (2) the coke ovens, grouped into one or more batteries, with equipment for charging and discharging the ovens, and for quenching; (3) a by-products plant for recovery of gas and chemical products (Lloyd 1971).
Redmond and colleagues (1972) found the excess lung cancer limited to men employed at the ovens, with an SMR of 250. The greatest burden of risk was further borne by men working on the tops of the ovens, with an SMR of about 500, rising to 1000 for men employed at least five years. Lung cancer risk was further related to temperature of carbonization. Methodological innovations of this study thus included the use of job title (usual position on the coke oven) as a kind of dosage surrogate. Polynuclear aromatic hydrocarbons are now considered to be the major carcinogens in coke oven effluents (International Agency for Research on Cancer 1984).

\section{Asbestos}

It is impossible to discuss the development of occupational epidemiology without recognizing the extensive contributions of Irving Selikoff. Selikoff first gained fame as a developer of isoniazid for therapy of tuberculosis, but is best known for his many contributions to occupational epidemiology, done in collaboration with E. Cuyler Hammond of the American Cancer Society, which fixed asbestos as a major industrial cancer hazard. Asbestos is a highly fire-resistant mineral that has been used in construction and textiles since the late $19^{\text {th }}$ century. Lack of even the most elementary industrial hygiene control (Fig. 5) has resulted in the deaths of tens of thousands of workers.

Selikoff's studies made extensive use of union (rather than employer) employment and health records. With the cooperation of the International Association of Heat and Frost Insulators and Asbestos Workers, he prepared a list of every member of two New Jersey locals as of December 31, 1942 $(\mathrm{N}=632)$. The original 632 men contributed less than 9000 person-years of "exposure to risk of death," which is rather small for a modern-day cohort study. Between 1943 and 1962, 45 of the 632 insulation workers died of cancer of the lung or pleura, where only 6.6 deaths were expected. Three of the pleural cancers were mesotheliomas, and there was one death from peritoneal mesothelioma. An unexpectedly large number of men died of cancer of the stomach, colon, or rectum ( 29 vs. 9.4 expected), and 12 died of asbestosis, which was so rare that comparative population rates were unavailable (Selikoff et al. 1964).

Selikoff later carried out a much larger study, using the membership of 120 locals of the International Union. A total of 17800 men were enrolled as of January 1,1967, and traced for at least 10 years, at which time over 12000 had at least 20 years of occupational exposure to asbestos. A number of methodological explorations were made, including use of alternative control groups, different methods for taking 


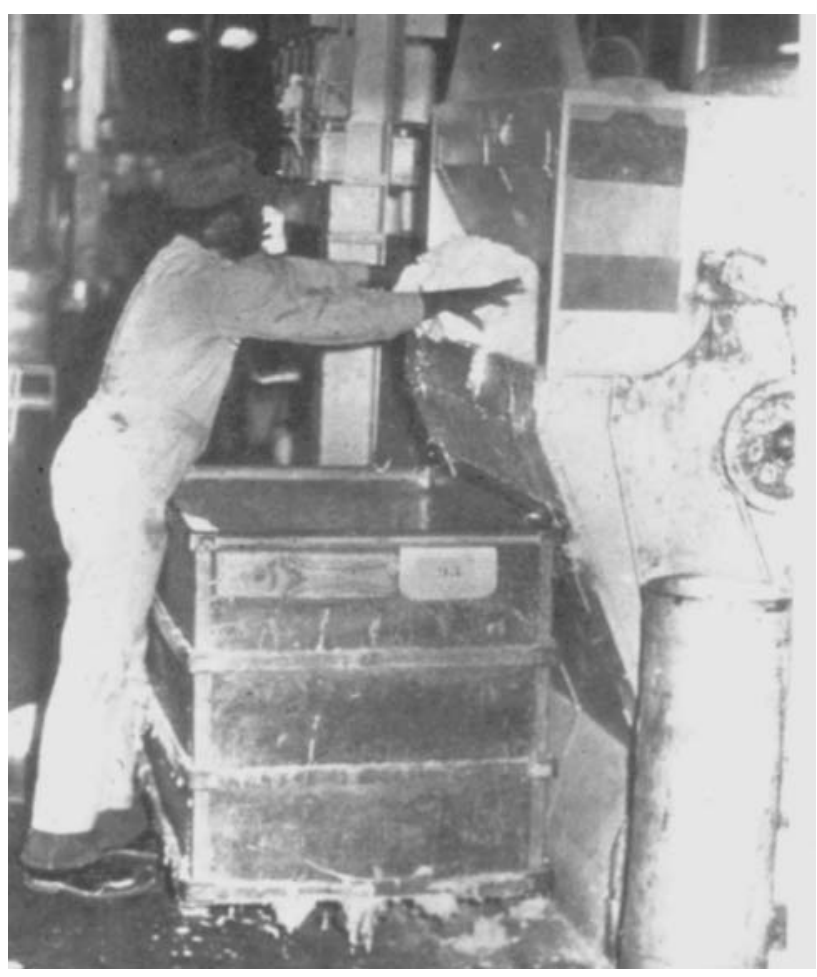

Figure 5 Worker loading chrysotile asbestos fiber by hand and without respiratory protection into the feed hopper of a carding machine at Marshville, NC, textile plant, prior to plant's acquisition and redesign by Raybestos Manhattan in 1969 (Lewinsohn et al. 1979)

smoking into account, and use of "best evidence" of cause of death, in place of unverified death certificate information (Hammond et al. 1979) (Tab. 3). In another ground-breaking study, death rates from two extremely rare cancers, pleural and peritoneal mesothelioma, were tabulated by duration of employment (Tab. 4). The dramatic dose-responses observed greatly reinforced the argument that asbestos insulation work was a severe cancer hazard (Selikoff et al. 1979).
Table 3 Deaths among 17800 asbestos insulation workers in the U.S. and Canada, January 1, 1967 - December 31, 1976 (166 853 man-years of observation) (Selikoff et al. 1979)

\begin{tabular}{|c|c|c|c|c|c|}
\hline \multirow{2}{*}{$\begin{array}{l}\text { Underlying } \\
\text { cause of } \\
\text { death }\end{array}$} & \multirow{2}{*}{$\begin{array}{l}\text { Expect- } \\
\text { ed }^{a}\end{array}$} & \multicolumn{2}{|c|}{ Observed } & \multicolumn{2}{|c|}{ Ratio (o/e) } \\
\hline & & (BE) & (DC) & (BE) & (DC) \\
\hline $\begin{array}{l}\text { Total deaths, } \\
\text { all causes }\end{array}$ & 1658.9 & 2271 & 2271 & 1.37 & 1.37 \\
\hline Cancer, all sites & 319.7 & 995 & 922 & 3.11 & 2.88 \\
\hline \multicolumn{6}{|l|}{$\begin{array}{l}\text { Deaths of less } \\
\text { common mali- } \\
\text { gnant neoplasms }\end{array}$} \\
\hline Pancreas & 17.5 & 23 & 49 & 1.32 & 2.81 \\
\hline $\begin{array}{l}\text { Liver, biliary } \\
\text { passages }\end{array}$ & 7.2 & 5 & 19 & 0.70 & 2.65 \\
\hline Bladder & 9.1 & 9 & 7 & 0.99 & 0.77 \\
\hline Testes & 1.9 & 2 & 1 & - & - \\
\hline Prostate & 20.4 & 30 & 28 & 1.47 & 1.37 \\
\hline Leukemia & 13.1 & 15 & 15 & 1.15 & 1.15 \\
\hline Lymphoma & 20.1 & 19 & 16 & 0.95 & 0.80 \\
\hline Skin & 6.6 & 12 & 8 & 1.82 & 1.22 \\
\hline Brain & 10.4 & 14 & 17 & 1.35 & 1.63 \\
\hline
\end{tabular}

a Expected deaths are based upon white male age-specific U.S. death rates from U.S. National Center for Health Statistics, 1967-1976.

(BE) Best evidence. Number of deaths categorized after review of best available information (autopsy, surgical, clinical).

(DC) Number of deaths as recorded from death certificate information only.

Selikoff and Hammond used their data to propound the concept of synergism, in which the disease rate among persons exposed to two hazards (e.g., asbestos and smoking) is much greater than that predicted additively from the individual exposures (Hammond et al. 1979). This required identification of a suitable non-exposed "control" population socioeconomically similar to the exposed insulation workers, and for whom detailed smoking data were available. Such a

Table 4 Deaths and death rates from pleural and peritoneal mesothelioma among 17800 asbestos insulation workers in the U.S. and Canada, January 1, 1967 - December 31, 1976 (Selikoff et al. 1979).

\begin{tabular}{|c|c|c|c|c|c|c|c|c|}
\hline \multirow{2}{*}{$\begin{array}{l}\text { Duration } \\
\text { from onset } \\
\text { (Years) }\end{array}$} & \multirow{2}{*}{$\begin{array}{l}\text { Number } \\
\text { of men }\end{array}$} & \multirow{2}{*}{$\begin{array}{l}\text { Person- } \\
\text { years of } \\
\text { observation }\end{array}$} & \multicolumn{2}{|c|}{ Number } & \multirow{2}{*}{$\begin{array}{l}\text { No. per } 1000 \text { person- } \\
\text { years of observation } \\
\text { (BE) }\end{array}$} & \multicolumn{2}{|c|}{ Number } & \multirow{2}{*}{$\begin{array}{l}\text { No. per } 1000 \text { person- } \\
\text { years of observation } \\
(B E)\end{array}$} \\
\hline & & & (BE) & (DC) & & (BE) & (DC) & \\
\hline$<10$ & 8190 & 26393 & 0 & 0 & 0 & 0 & 0 & 0 \\
\hline $10-14$ & 9063 & 29003 & 0 & 0 & 0 & 0 & 0 & 0 \\
\hline $15-19$ & 9948 & 34066 & 2 & 2 & 0.06 & 3 & 0 & 0.09 \\
\hline $20-24$ & 8887 & 31268 & 6 & 4 & 0.19 & 3 & 2 & 0.10 \\
\hline $25-29$ & 6596 & 20657 & 13 & 5 & 0.63 & 19 & 3 & 0.92 \\
\hline $30-34$ & 3547 & 11598 & 9 & 3 & 0.78 & 23 & 6 & 1.98 \\
\hline $35-39$ & 2020 & 5403 & 15 & 4 & 2.78 & 19 & 5 & 3.52 \\
\hline $40-44$ & 1108 & 3160 & 4 & 3 & 1.27 & 16 & 3 & 5.06 \\
\hline $45+$ & 1448 & 5305 & 14 & 4 & 2.64 & 29 & 5 & 5.47 \\
\hline
\end{tabular}

(BE) Best evidence. Number of deaths categorized after review of best available information (autopsy, surgical, clinical). (DC) Number of deaths as recorded from death certificate information only.

Soz.- Präventivmed. 48 (2003) 151-160

(c) Birkhäuser Verlag, Basel, 2003 
Table 5 Comparison of observed cancer death rates with predictions of additive and multiplicative models, according to source of cause-ofdeath information (adapted from Hammond et al. 1979)

\begin{tabular}{lcc}
\hline \multirow{2}{*}{ Exposure } & \multicolumn{2}{c}{ Lung cancer death rate, based upon: } \\
\cline { 2 - 3 } & "Best evidence" & Death certificate \\
\hline $\begin{array}{l}\text { Neither smoking nor } \\
\text { asbestos }\end{array}$ & 11.3 & 11.3 \\
$\begin{array}{l}\text { Smoking only } \\
\text { Asbestos only }\end{array}$ & 122.6 & 122.6 \\
$\begin{array}{l}\text { Both } \\
\text { actual }\end{array}$ & 80.2 & 58.4 \\
$\begin{array}{l}\text { Predicted from model } \\
\text { additive model }\end{array}$ & 693.8 & 601.6 \\
$\begin{array}{l}\text { Multiplicative (synergistic) } \\
\text { model }\end{array}$ & 870.1 & 169.7 \\
\hline
\end{tabular}

Zusammenfassung

Fragen der Kausalität in der Geschichte der Arbeitsepidemiologie

Die Arbeitsepidemiologie hat ihre Wurzeln in der klassischen Medizin. Allerdings wurde sie erst im 20. Jahrhundert zu einer quantitativen Wissenschaft. Dies dank der Pionierarbeiten von Personen und Organisationen wie Case, Lloyd und Selikoff und der "Division of Occupational Health" (Abteilung für Arbeitsschutz) des „U.S. Public Health Service” (öffentliches Gesundheitswesen). Studien mit Arbeitern in der chemischen Farbenindustrie, in Bitumenkohleminen, Erzhütten und Uranminen haben ganz besonders zu Neuerungen in methodischer Hinsicht, aber auch zur Entwicklung einer logischen Beweisführung beigetragen, was letztendlich zur Akzeptanz von kausalen Zusammenhängen zwischen Umweltbelastungen am Arbeitsplatz und dem Auftreten von Atemwegerkrankungen und Krebs führte. Die Kooperation mit Gewerkschaften, wie jenen der Stahl- und Asbestarbeiter, war für die Erfassung bedeutungsvoller Daten oft ausschlaggebend. group was found among the half-million men enrolled in the American Cancer Society's Cancer Prevention Study (CPS-I) (Hammond 1966). A comparison of death rates for lung cancer using additive and multiplicative (synergistic) models is shown in Table 5. The observed rates are predicted far better by the multiplicative model. This powerful demonstration of synergy was an early example of the epidemiological concept of interaction. Although initially developed for study of disease risk in relation to multiple occupational and lifestyle factors, techniques for assessing interactions are rapidly being adapted for use in studies of the joint genetic and environmental impact on disease risk (Andrieu \& Goldstein 1998). A foreseeable consequence of these methodological advances in assessing gene-environment interactions in the occupational setting is labeling the workers according to their susceptibility. The availability of such information raises ethical issues regarding the protection of workers from occupational hazards (Hemstreet 1998).

\section{Acknowledgement}

This work was supported by grants Ca-17613, CA-68384, and CA-91401 from the US Public Health Service.

Résumé

Questions de causalité dans l'histoire de l'épidémiologie des maladies professionnelles

L'épidémiologie des maladies professionnelles plonge ses racines dans la médecine classique. Cependant, elle n'est devenue une discipline quantitative qu'au $20^{\text {ème }}$ siècle, grâce au travail de pionnier d'individus tels que Case, Lloyd et Selikoff, ainsi que des organisations telle que la Division de Santé au Travail du service américain de Santé Publique. Des études sur les ouvriers de l'industrie chimique de la teinture, des mines de charbon, des fonderies ou des mines d'uranium ont été des sources particulièrement importantes d'innovation méthodologique et de développement du raisonnement logique aboutissant à l'acceptation de relation causale entre des expositions professionnelles et des maladies respiratoires ou le cancer. La collaboration de syndicats professionnels, tels que ceux des ouvriers de la sidérurgie ou travaillant avec l'amiante, a souvent été déterminante pour l'obtention de données essentielles. 


\section{References \\ Agricola G (Tr1950). De Re Metallica [1556] Transl. Hoover HC, Hoover LH. New York: Dover. \\ Andrieu N, Goldstein AM (1998). Epidemiologic and genetic approaches in the study of gene-envi- ronment interaction: an overview of available methods. Epidemiol Rev 20: 137-47. \\ Archer VE, Magnuson HJ, Holaday DA, Lawrence PA (1962). Hazards to health in ura- nium mining and milling. J Occup Med 4: 55-60.}

Averill E, Samuels $S W$ (1992). International occupational and environmental health. In: Rom WN, ed. Environmental and occupational medicine. $2^{\text {nd }} e d$. Boston: Little, Brown: 1357-64.

Breslow NE, Day NE (1987). Statistical methods in cancer research. Vol. II, The design and analysis of cohort studies. Lyon: International Agency for Research on Cancer: 11.

Case RAM, Hosker ME, McDonald DB, Pearson $J T$ (1954). Tumours of the urinary bladder in workmen engaged in the manufacture and use of certain dyestuff intermediates in the British chemical industry. Part 1, The role of aniline, benzidine, alpha-naphthylamine and beta-naphthylamine. Brit J Indust Med 11: 75-104.

Case RAM, Lea AJ (1955). Mustard gas poisoning, chronic bronchitis, and lung cancer: an investigation into the possibility that poisoning by mustard gas in the 1914-18 war might be a factor in the production of neoplasia. Brit J Prev Soc Med 9: 62-72.

Case RAM, Pearson JT (1954). Tumours of the urinary bladder in workmen engaged in the manufacture and use of certain dyestuff intermediates in the British chemical industry. Part 2, Further considerations of the role of aniline and of the manufacture of auramine and magenta (fuchsine) as possible causative agents. Brit J Indust Med 11: 213-6.

Collins EL, Gilchrist JC (1928). Effects of dust upon coal trimmers. J Indust Hyg 10: 101-10.

Court Brown WM, Doll R (1957). Leukaemia and aplastic anemia in patients irradiated for ankylosing spondylitis. London: Her Majesty's Stationery Office. (Medical Research Council. Special report series; No. 295).

Cutler SJ, Ederer F (1958). Maximum utilization of the life table method in analyzing survival. J Chronic Dis 8: 699-712.

Doyle HN (1969). Pneumoconiosis in bituminous coal miners. In: Lainhart WS, Doyle HN, Enterline PE, Henschel A, Kendrick MA, eds. Pneu- moconiosis in Appalachian bituminous coal miners. Washington DC: USDHEW Public Health Service Bureau of Occupational Safety and Health: 3-20.

Hammond EC, Selikoff IJ, Seidman H (1979). Asbestos exposure, cigarette smoking and death rates. Ann NY Acad Sci 330: 473-90.

Hammond EC (1966). Smoking in relation to death rates of one million men and women. Natl Cancer Inst Monogr 19: 127-204.

Härting FH, Hesse W (1879). Der Lungenkrebs, die Bergkrankheit in den Schneeberger Gruben. Vierteljahreschr Gerichtl Med Offentl Gesundheitswesen 31: 102-32, 313-37.

Hemstreet GP (1998). Renal-urinary system. In: Encyclopaedia of occupational health and safety Vol. 1. (ed: Stellman JM), Chapter 8. $4^{\text {th }}$ ed. Geneva: ILO.

Hill $A B$ (1953). Observation and experiment. N Engl J Med 248: 995-1001.

Hunter $D$ (1969). The disease of occupations. $4^{\text {th }}$ ed. Boston: Little, Brown.

International Agency for Research on Cancer, ed. (1984). IARC monographs on the evaluation of the carcinogenic risk of chemicals to humans. Polynuclear aromatic compounds. Part 3, Industrial exposure in aluminum production, coal gasification, coke production, and iron and steel founding. Vol. 34. Lyon: IARC: 133-90.

International Agency for Research on Cancer, ed. (1987). Arsenic. In: IARC monographs on the evaluation of carcinogenic risks to humans. Suppl. 7, Overall evaluations of carcinogenicity: an updating of IARC monographs 1 to 42 . Lyon: IARC: $100-6$.

Lainhart WS, Doyle HN, Enterline PE, Henschel $A$, Kendrick MA, eds. (1969). Pneumoconiosis in Appalachian bituminous coal miners. Washington DC: USDHEW Public Health Service Bureau of Occupational Safety and Health.

Lee AM, Fraumeni JF Jr (1969). Arsenic and respiratory tract cancer in man: an occupational study. J Natl Cancer Ins 42: 1045-52.

Lewinsohn HC, Kennedy CA, Day JE, Cooper $P H$ (1979). Dust control in a conventional asbestos textile factory. Ann NY Acad Sci 330: 225-41.

Lind J (1757; 1974). A treatise on the scurvy in three parts, containing an inquiry in the nature, causes, and cure of that disease together with a critical and chronological view of what has been published on the subject. $2^{\text {nd }}$ ed. London: A. Millar. Reprint: Prev Med 3: 300-5.
Lloyd JW, Ciocco A (1969). Long-term mortality study of steelworkers. 1, Methodology. J Occup Med 11: 299-310.

Lloyd JW (1971). Long-term mortality study of steelworkers. 5, Respiratory cancer in coke plant workers. J Occup Med 13: 53-68.

Lorenz E (1944). Radioactivity and lung cancer: critical review of lung cancer in miners of Schneeberg and Joachimsthal. J Natl Cancer Ins 5: $1-15$.

Milham S Jr, Strong T (1974). Human arsenic exposure in relation to a copper smelter. Environ Res 7: 176-82.

Pendergrass EP, Lainhart WS, Bristol LJ, Felson $B$, Jacobson $G$ (1972). Historical perspectives of coal workers' pneumoconiosis in the United States. Ann NY Acad Sci 200: 835-54.

Pinto SS, Bennett BM (1963). Effect of arsenic trioxide exposure on mortality. Arch Environ Health 7: 583-91.

Pinto SS, McGill CM (1953). Arsenic trioxide exposure in industry. Ind Med Surg 22: 281-7.

Plinius Secundus $C(\operatorname{Tr} 1929)$. Naturalis historiae. Book 2. In: Bailey KC. The elder Pliny's chapters on chemical subjects. Transl. part 1. London: Arnold.

Polednak AP, Stehney AF, Rowland RE (1978). Mortality among women first employed before 1930 in the U.S. radium dial-painting industry. Am J Epidemiol 107: 179-95.

Ramazzini B (Tr1940). De morbis artificum [1713] Transl. Wright WC. Diseases of workers. Chicago: University of Chicago Press.

Redmond CK, Ciocco A, Lloyd JW, Rush HW (1972). Long-term mortality study of steelworkers. 6, Mortality from malignant neoplasms among coke oven workers. J Occup Med 14: 621-9.

Registrar-General (1938). Occupational mortality: census of England and Wales. 1931, Decennial supplement, part 2a. London: Her Majesty's Stationer's Office.

Rehn L (1895). Blasengeschwülste bei Fuchsin Arbeitern. Arch Klin Chir 50: 588-600.

Selikoff IJ, Churg J, Hammond EC (1964). Asbestos exposure and neoplasia. JAMA 188: 22-6.

Selikoff IJ, Hammond EC, Seidman H (1979). Mortality experience of insulation workers in the United States and Canada, 1943-1976. Ann NY Acad Med 330: 91-116. 
Stellman JM, Kabat $G$ (1978). An assessment of the health effects of arsenic germane to low-level exposure. Report to USEPA Science Advisory Board Study Group, October. Washington DC: U.S. Environmental Protection Agency.

Stellman JM, Stellman SD, Christian R, Weber T, Tomasallo $C$ (2003). The extent and patterns of usage of Agent Orange and other herbicides in Vietnam. Nature 422: 681-7.

Stellman SD, Stellman JM, Sommer JF Jr (1988). Combat and herbicide exposure in Vietnam among American legionnaires. Environ Res 47: 112-28.

Stellman SD, Demers PA, Colin D, Boffetta P (1998). Cancer mortality and wood dust exposure among American Cancer Society Cancer Prevention Study-II (CPS-II) participants. Amer J Indust Med 34: 229-237.
U.S. Public Health Service, ed. (1964). Smoking and health: a report of the advisory committee to the Surgeon-General of the Public Health Service. Washington DC: USDHEW.

Visconti L (1870). Protocollo generale delle necropsie eseguite nell' Istituto Anatomo Patologico dell' Ospedale Maggiore. Milan, Ospedale Maggiore.

Wagoner JK, Archer VE, Carroll BE, Holaday DA, Lawrence PA (1964a). Cancer mortality patterns among U.S. uranium miners and millers, 1950 through 1962. J Natl Cancer Ins 32: 787-801.

Wagoner JK, Archer VE, Carroll BE, Holaday DA, Lawrence PA (1964b). Mortality patterns among United States uranium miners and millers, 1950-1962; preliminary report. In: Radiological health and safety in mining and milling of nuclear materials. Vol. 1. Vienna: International Atomic Energy Agency: 37-48.
Wagoner JK, Archer VE, Lundin FE, Holaday $D A$, Lloyd JW (1965). Radiation as a cause of lung cancer among uranium miners. $\mathrm{N}$ Engl J Med 273: 181-8.

Zenker FA (1867). Über Staubinhalationskrankheiten der Lungen. Arch Clin Med 2: 116-71.

Address for correspondence

Steven D. Stellman, Ph.D. M.P.H.

Department of Epidemiology

Mailman School of Public Health

630 West 168th Street - PH-18

USA-New York, NY 10032

Tel.: +1 212-305-4911

Fax: +1 212-305-9413

e-mail: sds91@columbia.edu 